\title{
Micronutrient deficiency in premature infants after hospital discharge: what is the evidence of free access in the last five years?
}

\author{
Brunnella Alcantara Chagas de Freitas ${ }^{1 *}\left(\mathbb{D}\right.$, Kelvin Oliveira Rocha ${ }^{1}(\mathbb{B}$, \\ Luiz Felipe Gonçalves de Figueiredo' ${ }^{1}$, Daniela Rezende Moreira' ${ }^{1}$,

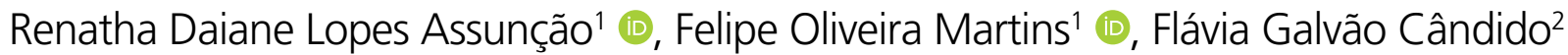

\section{INTRODUCTION}

The preterm population is at increased risk for micronutrient deficiency, a situation that requires adequate supplementation, due to the risk of causing sensorimotor, cognitive, behavioral and somatic growth changes ${ }^{1,2}$. There are recommendations from scientific institutions about supplementation with iron, multivitamin and zinc for premature children ${ }^{3,4}$.

The imbalance between the supply and demand of nutrients, associated with low reserve, are conditions that justify the need to supplement micronutrients for premature children. As approximately $80 \%$ of the iron reserve is made in the third trimester of pregnancy, premature babies are born with reduced iron deposits 5 . The zinc deposit in hepatocytes is also relatively smaller due to the smaller size of the liver ${ }^{6}$. In addition, the deficiency in micronutrient intake may be associated with low availability of breast milk, making the children unable to meet the demands of rapid growth in the first months of life ${ }^{7}$. Several other factors are related to micronutrient deficiency and prematurity. Family income and maternal schooling are relevant socioeconomic risk factors. In addition, low birth weight stands out as a biological risk factor ${ }^{8}$.

Many studies assess micronutrient deficiencies and supplementation in premature infants during the hospitalization period, however, there is a shortage of these analyses in the course of the first years of life, after discharge from hospital. In this context, this systematic review aims to analyze the scientific evidence, published in the last five years, regarding the association between prematurity and micronutrient deficiency in the period after hospital discharge.

\section{METHODS}

The systematic review was based on the recommendations of the Preferred Reporting Items for Systematic Reviews (PRISMA) at all stages of design, implementation and reporting?

\section{Database and search strategy}

The bibliographic survey was carried out between June and July, 2019, in the following databases: Publisher Medline (PubMed) and Virtual Health Library (VHL). Manual searches of the references in the selected studies were also carried out in order to identify articles that were not found in the databases, which were submitted to the same analysis protocol. As a search engine, we used the term "premature infant" combined with the following descriptors: "micronutrients", "anemia", "iron deficiency", "zinc", "vitamin A" and Vitamin D". The following filters were selected: humans; free full text; past five years; English, Portuguese or Spanish.

\section{Eligibility criteria and study selection}

The inclusion criteria for the review were: any original article that assessed micronutrient deficiency in premature infants after

\footnotetext{
'Universidade Federal de Viçosa, Department of Medicine and Nursing - Viçosa (MG), Brazil.

¿Universidade Federal de Viçosa, Postgraduate Program in Nutrition Science - Viçosa (MG), Brazil.

*Corresponding author: brupediatria@gmail.com

Conflicts of interest: the authors declare there are no conflicts of interest. Funding: none.

Received on September 25, 2020. Accepted on November 01, 2020.
} 
hospital discharge; and that was published in the past five years. The exclusion criteria were: studies that did not assess premature infants; studies that evaluated only the period of hospitalization in the neonatal intensive care unit, as well as reviews, congress publications, theses and dissertations. Two independent reviewers carried out the selection of studies in two phases, including analysis of the title, summary and reading of the full text. A third reviewer resolved the disagreements. The steps included identification of articles in the databases, exclusion of duplicate files, initial selection by title and reading of the abstract, and complete analysis of the manuscripts that met the eligibility criteria. Duplicate articles in different databases were identified using the Mendeley Desktop software.

\section{SYSTEMATIZATION OF RESULTS}

The extraction and systematization of the results were performed in a Microsoft Excel $^{\oplus}$ document and following the specific purposes of knowing the prevalence and factors associated with anemia or deficiencies of iron, zinc and vitamins A and D.

The initial screening identified 987 titles. After removing the duplicate files, 491 articles were analyzed. Of these, 460 were excluded after reading the title and summary, totaling 31 remaining articles. After the complete reading to assess the pre-established eligibility criteria, four original articles were included in this review. The details of the selection process are shown in Figure 1. The main characteristics of the studies are shown in Table 1 . The results were organized according to the following themes: a) anemia and iron deficiency in preterm children; b) zinc in preterm children; c) vitamins and prematurity.

\section{Anemia and iron deficiency in preterm children}

The three studies, all carried out in Brazil, assume different criteria for the biochemical definition of iron deficiency and anemia. The work of Ferri et al. $(2014)^{8}$ defines iron deficiency and anemia by ferritin $<10 \mathrm{ng} / \mathrm{mL}$ and hemoglobin $<10 \mathrm{~g} / \mathrm{mL}$. Yamada \& Leone $(2014)^{5}$ characterize anemia by hemoglobin levels $<10.5 \mathrm{~g} / \mathrm{mL}$, not specifying which ferritin levels define iron deficiency. Freitas et al. $(2016)^{7}$ characterize iron deficiency by ferritin levels $<30 \mathrm{ng} / \mathrm{mL}$ and use more detailed criteria for anemia, which varies according to the corrected gestational age (CGA) and the child's weight: (a) $\mathrm{Hb}<8,5 \mathrm{~g} / \mathrm{dL}$ (weight $\leq 1500 \mathrm{~g}$ ) and $\mathrm{Hb}<9.0 \mathrm{~g} / \mathrm{dL}$ (weight between 1500-2000 g) for IGC between six to eight weeks; (b) $\mathrm{Hb}<9.0$ (weight $\leq 1500 \mathrm{~g}$ ) and $\mathrm{Hb}<9.5$ (weight between 1500-2000g) for CGA from eight to ten weeks; (c) $\mathrm{Hb}<10$ $\mathrm{g} / \mathrm{dL}$ for 6 -month CGA; (d) $\mathrm{Hb}<11 \mathrm{~g} / \mathrm{dL}$ for CGA beyond
6 months. These divergences in the used criteria make it difficult to compare results between studies.

The hematological evolution of preterm infants in the first months is significantly different from children born at term, even with the corrected gestational age. The Yamada \& Leone $(2014)^{5}$ cohort compared the biochemical characteristics between two groups of children (late preterm and full term), during the first two months of life, and considering the CGA. The study points out that the levels of hemoglobin, hematocrit and reticulocytes decrease in both groups with advancing age; however, these values are significantly lower in the group of late preterm infants. In addition, the mean ferritin levels were similar between groups. Thus, this inference shows a type II error of $42 \%$ due to sample size.

The prevalence of anemia and iron deficiency tends to increase with the advancement of CGA in the first months of life $^{7}$. In premature infants, micronutrients are rapidly depleted due to the rapid expansion of erythrocytes, which accompanies the growth process in the first weeks after birth. In the cohort of Freitas et al. (2016) ${ }^{7}$, the prevalence of anemia and iron deficiency was, respectively, $36.7 \%$ and $25.7 \%$, with one month of CGA, and $38.3 \%$ and $68.9 \%$ at six months of CGA, with a margin error of $12 \%$ due to sample size. In contrast, in the cohort of Ferri et al. $(2014)^{8}$, the prevalence of anemia and iron deficiency was $26.5 \%$ and $48 \%$, respectively, with a margin of error of $6 \%$, with one year of CGA. It is worth mentioning the different methodologies of the studies in the characterization of anemia and iron deficiency, affecting the observed prevalence rates.

Socioeconomic factors have an impact on the prevalence of anemia and iron deficiency ${ }^{8}$. In the cohort of Ferri et al. $(2014)^{8}$, anemia was associated with the level of maternal schooling, number of pregnancies, family income and family history of alcoholism. Freitas et al. (2016) ${ }^{7}$ corroborate these associations when verifying that maternal schooling is a predictor of low adherence to the use of recommended supplements, and that anemia in groups of premature infants who have low adherence to supplementation tends to be 2.5 times more prevalent. However, anemia is observed in 34\% of premature infants at six months of CGA (margin of error of $15 \%$ ), even when there is adequate adherence to micronutrient supplements, a relevant fact that signals a multifactorial etiology?

Ferri et al. $(2014)^{8}$ relate the consumption of cow's milk at six months of CGA to the 1.7-fold increase in the risk of anemia at twelve months of CGA. Cow's milk, in addition to having low iron bioavailability, generates an environment rich in proteins that are difficult to digest, such as casein, and minerals, such as calcium, which impair iron absorption ${ }^{8}$. 
As adverse effects of ferrous sulphate supplementation, nausea, vomiting, abdominal discomfort and constipation were reported in $19 \%$ of premature infants participating in the study by Freitas et al. $(2016)^{7}$, solved after replacement with other iron compounds.

The studies converge on the aspects that anemia is prevalent in the premature population, with emphasis on families that have socioeconomic vulnerability, and that iron supplementation should be performed. The early insertion of cow's milk is highlighted as a factor associated with iron deficiency and anemia.

\section{Zinc in preterm children}

Two studies, both Brazilian, assess zinc in premature children, and one of them describes the doses of zinc supplementation and the levels of serum zinc that characterize their deficiency ${ }^{7,8}$. Both converge on the appropriate supplementation period, between 36 weeks and six months of CGA. Freitas et al. (2016) ${ }^{7}$ used a daily dose of $0.5 \mathrm{mg} / \mathrm{kg}$ and considered a serum level of serum zinc below $70 \mu \mathrm{g} / \mathrm{dL}$ as a deficiency.

Ferri et al. $(2014)^{8}$ found no association between zinc supplementation before 6 months of CGA and the presence of anemia at 12 months of CGA; however, in this study, only $20 \%$ of premature infants received zinc supplementation before 6 months of CGA.

On the other hand, Freitas et al. (2016) ${ }^{7}$, when assessing preterm infants at six months of CGA, showed that $36 \%$ had zinc deficiency (margin of error of 14\%), and found associations between low adherence to micronutrient supplementation,

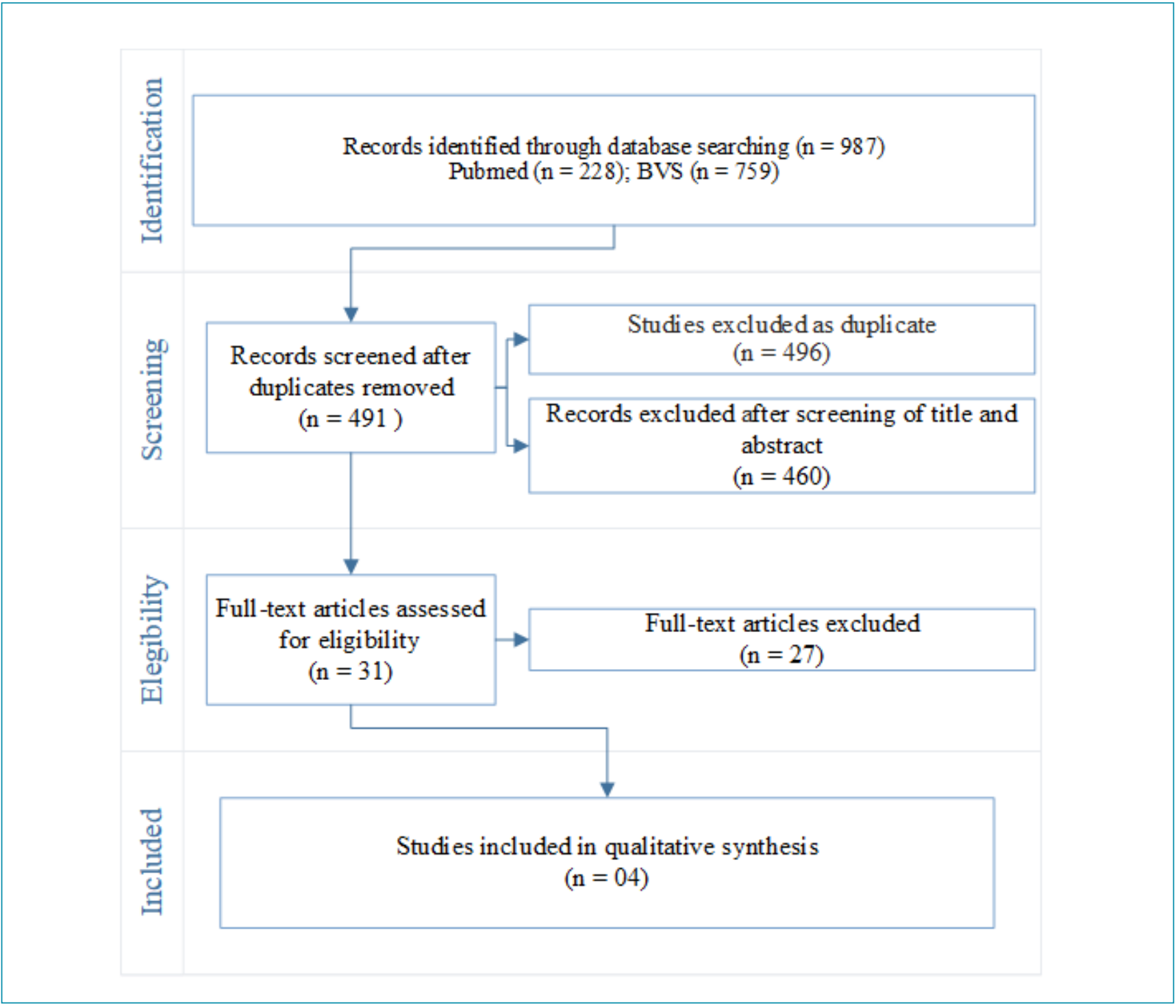

Figure 1. Flowchart of bibliographic research and study selection procedures, as recommended by PRISMA. 
lower serum zinc levels and higher frequency of their deficiency. They also observed that $75 \%$ of premature infants with low adherence to supplementation presented with zinc deficiency, and this condition was 3.1 times more prevalent among the low adherence group when compared to the group with adequate adherence.

Zinc supplementation is recommended for premature children in the first six months of CGA, and inadequate zinc supplementation is associated with a greater chance of developing their disability ${ }^{3,7}$.

\section{Vitamins and prematurity}

Two studies looked at serum vitamin levels in preterm infants, one Brazilian and one Polish. The study by Freitas et al. (2016) evaluated vitamin A levels, and its deficiency was defined by serum retinol levels below $0.2 \mathrm{mg} / \mathrm{L}$. Czech-Kowalska et al. (2016) ${ }^{10}$ evaluated the levels of 25-hydroxyvitamin D (25$\mathrm{OHD}$ ) on a continuous scale in premature children at 40 weeks and 3 months of CGA.

In the study by Freitas et al. $(2016)^{7}, 24 \%$ of children with one month of CGA showed vitamin A deficiency,

\begin{tabular}{|c|c|c|c|c|c|c|c|c|}
\hline $\begin{array}{l}\text { Author } \\
\text { (year) }\end{array}$ & Country & $\begin{array}{l}\text { Study } \\
\text { Type }\end{array}$ & $\begin{array}{c}\text { Sample } \\
\text { Size }\end{array}$ & $\begin{array}{c}\text { Studied } \\
\text { Population }\end{array}$ & Age & $\begin{array}{l}\text { Main } \\
\text { methodological } \\
\text { aspects }\end{array}$ & Outcomes & Results \\
\hline $\begin{array}{l}\text { Yamada } \\
\text { et al., } \\
2014^{5}\end{array}$ & Brazil & $\begin{array}{c}\text { Prospective } \\
\text { Cohort }\end{array}$ & $25 / 21$ & $\begin{array}{l}\text { Late } \\
\text { preterm } \\
\text { and term }\end{array}$ & $\begin{array}{l}\text { First } 2 \\
\text { months }\end{array}$ & $\begin{array}{l}\text { serial blood } \\
\text { iron deficiency } \\
\text { markers } \\
\text { of preterm } \\
\text { and term } \\
\text { comparison }\end{array}$ & $\begin{array}{l}\text { Comparison of } \\
\text { hematological } \\
\text { parameters and } \\
\text { systemic iron } \\
\text { content between } \\
\text { late term and term }\end{array}$ & $\begin{array}{c}\text { Iron deficiency } \\
\text { anemia markers significantly } \\
\text { increased in the past. }\end{array}$ \\
\hline $\begin{array}{l}\text { Ferri } \\
\text { et al., } \\
2014^{8}\end{array}$ & Brazil & $\begin{array}{c}\text { Prospective } \\
\text { Cohort }\end{array}$ & 310 & $\begin{array}{l}\text { Preterm } \\
\quad<34 \\
\text { weeks and } \\
<1500 \mathrm{~g}\end{array}$ & $\begin{array}{c}\text { First } \\
12 \\
\text { months }\end{array}$ & $\begin{array}{l}\text { Anthropometric } \\
\text { and dietary } \\
\text { data in the } \\
\text { neonatal period } \\
\text { and at six and } \\
12 \text { months } \\
\text { of corrected } \\
\text { age. Laboratory } \\
\text { tests at } 12 \\
\text { months. }\end{array}$ & $\begin{array}{l}\text { Iron deficiency } \\
\text { and anemia's } \\
\text { associated factors } \\
\text { prevalence }\end{array}$ & $\begin{array}{l}\text { Prevalence of anemia } \\
\text { and iron deficiency: } \\
26.5 \% \text { and } 48 \% \text {, } \\
\text { respectively. Associated } \\
\text { factors: consumption of } \\
\text { cow's milk, low maternal } \\
\text { age, multiparity and } \\
\text { being born small for } \\
\text { gestational age. }\end{array}$ \\
\hline $\begin{array}{l}\text { Freitas } \\
\text { et al., } \\
2016^{7}\end{array}$ & Brazil & $\begin{array}{l}\text { Prospective } \\
\text { Cohort }\end{array}$ & 58 & Preterm & $\begin{array}{l}\text { First } 6 \\
\text { months }\end{array}$ & $\begin{array}{l}\text { Laboratory } \\
\text { tests performed } \\
\text { at one and } \\
\text { six months } \\
\text { of corrected } \\
\text { age. Monthly } \\
\text { verification } \\
\text { of adherence } \\
\text { to the use of } \\
\text { prescribed } \\
\text { supplements. }\end{array}$ & $\begin{array}{l}\text { Prevalence of iron, } \\
\text { zinc and vitamin } \\
\text { A deficiencies } \\
\text { and associated } \\
\text { factors. Analysis of } \\
\text { adherence to the } \\
\text { use of prescribed } \\
\text { supplements. }\end{array}$ & $\begin{array}{l}\text { Prevalence of anemia, } \\
\text { iron and zinc deficiency } \\
\text { are higher in those } \\
\text { with less adherence to } \\
\text { supplements, which } \\
\text { was associated with low } \\
\text { maternal education. }\end{array}$ \\
\hline $\begin{array}{l}\text { Czech- } \\
\text { Kowalska } \\
\text { et al., } \\
2016^{10}\end{array}$ & Poland & $\begin{array}{c}\text { Prospective } \\
\text { Cohort }\end{array}$ & 290 & Preterm & $\begin{array}{l}\text { First } 3 \\
\text { months }\end{array}$ & $\begin{array}{l}\text { Anthropometry, } \\
\text { biochemical } \\
\text { and bone mass } \\
\text { analysis at } 40 \\
\text { weeks and at } \\
\text { three months } \\
\text { corrected. }\end{array}$ & $\begin{array}{l}\text { Verification } \\
\text { of clinical and } \\
\text { biochemical } \\
\text { parameters, } \\
\text { including bone } \\
\text { metabolism } \\
\text { markers, as } \\
\text { potential predictors } \\
\text { of bone mineral } \\
\text { content. }\end{array}$ & $\begin{array}{l}\text { Serum PTH can be a } \\
\text { simple predictor of } \\
\text { bone mineral content } \\
\text { in premature infants } \\
\text { at term, but urinary } \\
\text { phosphate and serum } \\
\text { osteocalcin excretion can } \\
\text { predict reduced bone } \\
\text { mineral content at } 3 \\
\text { months of age. }\end{array}$ \\
\hline
\end{tabular}


however, at 6 months of CGA, none of them was deficient $^{7}$. A significant portion of the population, $58 \%$, still did not use multivitamins in the first consultation after hospital discharge. The main adverse effects from the use of multivitamins reported in this study were nausea and vomiting, representing $7 \%$ of the sample. However, the adverse effects ceased after the trademark of these supplements was changed ${ }^{7}$.

According to the study by de Czech-Kowalska et al. $(2016)^{10}$, serum levels of 25-hydroxyvitamin-D (25-OHD) are not predictors of bone mass variation in premature infants. The mean serum 25-OHD levels did not differ between groups of premature infants with low or high bone mass density, with 40 weeks and six months of CGA. Furthermore, the mean serum 25-OHD values were significantly similar between the two periods ${ }^{10}$.

\section{LIMITATIONS AND PROSPECTS}

As limitations, the use of samples restricted to a single health center and the short time of clinical follow-up can be observed. The works of Yamada \& Leone $(2014)^{5}$ and Freitas et al. $(2016)^{7}$ have limitations in terms of sample size, with a margin of error above $10 \%$ in estimating prevalence. Ferri et al. $(2014)^{8}$ presented a considerable loss percentage and exclusion rate of participants. Czech-Kowalska et al. (2016) ${ }^{10}$ showed a bias in selecting their population, coming from a tertiary neonatal care unit that receives only external deliveries. In addition, all studies present a cohort design, so we did not find randomized clinical trials with this approach.

In contrast to the large number of studies carried out during the neonatal period and during hospitalization, there is a lack of robust evidence about micronutrient deficiencies, their supplementation and their long-term effects on the health of children born prematurely after hospital discharge. Thus, this is a fertile field for future research, mainly based on randomized clinical trials.

\section{CONCLUSION}

Anemia and iron and zinc deficiencies are prevalent among premature infants. Socioeconomic factors and low adherence to the use of supplements are associated with micronutrient deficiencies. Thus, micronutrient supplementation and monitoring of adherence are strategies for preventing micronutrient deficiencies; in addition, laboratory monitoring of hematological parameters and serum iron and zinc levels among premature infants is essential.

\section{AUTHORS' CONTRIBUTIONS}

BACF: Conceptualization, Methodology. KOR: Conceptualization, Methodology, Writing - Original Draft, Writing - Review \& Editing. LFGF: Conceptualization, Methodology. DRM: Conceptualization, Methodology. RDLA: Writing - Original Draft, Writing - Review \& Editing. FOM: Writing - Review \& Editing. FGC: Writing Review \& Editing.

\section{REFERENCES}

1. Mattei $D$, Pietrobelli A. Micronutrients and brain development. Curr Nutr Rep. 2019;8(2):99-107. https://doi.org/10.1007/ s13668-019-0268-z

2. McCarthy EK, Dempsey EM, Kiely ME. Iron supplementation in preterm and low-birth-weight infants: a systematic review of intervention studies. Nutr Rev. 2019;77(12):865-77. https:// doi.org/10.1093/nutrit/nuz051

3. Sociedade de Pediatria de São Paulo, Departamento de Pediatria da Associação Paulista de Medicina. Março lilás - suplementação de vitaminas e oligoelementos para o prematuro. São Paulo: Sociedade de pediatria de São Paulo; 2020. [cited on June 11, 2020]. Available from: https://www. spsp.org.br/2020/03/09/suplementacao-de-vitaminas-eoligoelementos-para-o-prematuro/
4. Silveira RC. Seguimento ambulatorial do prematuro de risco. Porto Alegre: Sociedade Brasileira de Pediatria. Departamento Científico de Neonatologia; 2012. [cited on Jun. 11, 2020]. Available from: https://www.sbp.com.br/ fileadmin/user_upload/2015/02/Seguimento_prematuro_ oficial.pdf

5. Yamada RT, Leone CR. Hematological and iron content evolution in exclusively breastfed late-preterm newborns. Clinics (Sao Paulo). 2014;69(12):792-8. https://doi.org/10.6061/ clinics/2014(12)01

6. Mathur NB, Agarwal DK. Zinc supplementation in preterm neonates and neurological development, a randomized controlled trial. Indian Pediatr. 2015;52(11):951-5. https:// doi.org/10.1007/s13312-015-0751-6 
7. Freitas BA, Lima LM, Moreira ME, Priore SE, Henriques BD, Carlos CF, et al. Micronutrient supplementation adherence and influence on the prevalences of anemia and iron, zinc and vitamin A deficiencies in preemies with a corrected age of six months. Clinics (Sao Paulo). 2016;71(8):440-8. https:// doi.org/10.6061/clinics/2016(08)06

8. Ferri C, Procianoy RS, Silveira RC. Prevalence and risk factors for iron-deficiency anemia in very-low-birth-weight preterm infants at 1 year of corrected age. J Trop Pediatr. 2014;60(1):5360. https://doi.org/10.1093/tropej/fmt077

9. Moher D, Liberati A, Tetzlaff J, Altman DG; PRISMA Group. Preferred reporting items for systematic reviews and meta-analyses: the PRISMA statement. PLoS Med. 2009;6(7):e1000097. https://doi.org/10.1371/journal. pmed.1000097

10. Czech-Kowalska J, Czekuc-Kryskiewicz E, Pludowski P, Zaniuk K, Jaworski M, Luba A, et al. The Clinical and biochemical predictors of bone mass in preterm infants. PLoS One. 2016;11(11):e0165727. https://doi.org/10.1371/journal. pone.0165727 